\title{
Practicing M-Application Services Opportunities with Special Reference to Oman
}

\author{
Syed Jafar Naqvi and Hafedh Al-Shihi \\ Sultan Qaboos University, Al-Khod, Oman
}

cce3249@squ.edu.om, hafedh@squ.edu.om

\begin{abstract}
Mobile technologies are opening new channels of communication for people and organizations. According to a survey by the World Bank (2012), no other technology has been in the hands of so many people in so many countries in such a short period. Mobile phones have become a "musthave" electronic gadget for daily business. These devices are likely replacing the need for laptops and desktops. Mobile phones are used for social networking, location-based services, navigation/local search, instant messaging and many other applications. Mobile devices are widely used not only by developed countries but also used by developing nations like the Gulf Cooperation Council (GCC) countries of which Oman is a member. A recent estimate indicated that over half of the Omani population has internet accessible mobile devices. The mobile devices are continuously getting more sophisticated and advanced; people are getting benefit of these devices in their everyday lives. This progression in mobile technologies has created opportunities and influenced various government organizations to go mobile with their services including Oman and its neighbouring countries. This research presents a synopsis of M-application services offered by many countries with special reference to Oman.
\end{abstract}

Keywords: Oman, Mobile technology, Internet, M-application services and SMSs.

\section{Introduction}

In conventional computing environment, to do computing, a person has to sit alongside with computer to complete the task. A computer can be a standalone PC, or connected to network or to a server, and so on via cable. This condition limits the use of computer and created hardship for individuals and workforce on the move. In today's era, mobile phones have become essential tools for voice calling, text messages, and accessing internet applications. Impact of mobile phones is humongous in our daily lives.

This research entirely focus on Omani initiatives, but a brief overview of mobile usage and applications in the neighbouring countries such as UAE, Qatar, Saudi Arabia, and Bahrain are also presented. In these countries, 7 out of 10 smart phone users use an application at least once every day and $35 \%$ of smart phone users who

Material published as part of this publication, either on-line or in print, is copyrighted by the Informing Science Institute. Permission to make digital or paper copy of part or all of these works for personal or classroom use is granted without fee provided that the copies are not made or distributed for profit or commercial advantage AND that copies 1) bear this notice in full and 2) give the full citation on the first page. It is permissible to abstract these works so long as credit is given. To copy in all other cases or to republish or to post on a server or to redistribute to lists requires specific permission and payment of a fee. Contact Publisher@InformingScience.org to request redistribution permission. download applications regularly have purchased at least one application in the last 30 days. This makes it very evident that customer engagement and organizational communication will both soon be occurring extensively through varieties of mobile applications accessed through smart phone and tablet devices in the very near future (UAE turn to mobile and social media applications, 2013). 
Currently, almost 30 government mobile applications are available in the UAE. Some of these included Ministry of Health (MOH) M-application service, which offers easy communication with the Ministry of Health's call center nearest to the users' current location. General Authority of Islamic Affairs and Endowments' services are offered via SMS such as Fatwas, Prayer Times, Qibla and location of the nearest Masjid. SEHA application offers information on ambulance services and an interactive map service that enables the users to find the nearest SEHA facility. Abu Dhabi CityGuard service offers service to report incidents and submit complaints related to the Abu Dhabi directly to the government. With Dubai Electric \& Water Authority (DEWA) Mapplication service, the user can view and pay utility bills online, get information about DEWA office location, contact details, working hours, and access many other services (UAE turn to mobile and social media applications, 2013).

In a typical household in Qatar owns three mobile phones, two computers, and one smart phone, and people are using this technology to access the Internet in ever-greater numbers. Many government agencies in Qatar have capitalized the opportunity and offered varieties of Mapplications to citizens such as Hukoomi service through which the users can pay utility bills using their mobile devices. Ministry of Municipality and Urban Planning (MMUP) has been proactively collaborating with various municipalities and other relevant agencies in the country to automate processes and ensure more and more services are on mobile phones. The Ministry of Justice (MOJ) is also offering a mobile hotline application service to keep records of users' inquiries, and sends them SMS notifications when their complaints are resolved. There are many other mobile applications are underway to be offered very soon (e-government on line services, 2013).

Bahrain has launched several smart phone applications for Android and iTunes platform, which grant users easy access to these eServices at any place and time. Some of these mobile applications include eGov SMS Services that generates SMS message requesting the users to use eGov eServices through smart devices. Non-Government Organizations (NGO) directory service which provides a list of all Non-Government organizations located in the Kingdom of Bahrain on users mobile devices. Health locator service provides an interactive map to locate health related services within the Kingdom of Bahrain. eKiosk \& eService Center Locator service provides convenient and accessible points where customers can use eGovernment online Services on the go. Gasoline Octane Inquiry application allows citizens and visitors to inquire about the suitable octane (fuel type) for their vehicles. Electricity \& Water Bill service is provided by the Electricity and Water Authority where individuals can inquire about their water and electricity bill by providing simple information available on the bill, such as the "ID No." as well as the "Account No.". Flight Information service enables individuals to inquire information about the expected Arrival and Departure timings of flights. The Ramadanyat application provides users with prayer times, information about Zakat, weather information in addition to Ramadan Majalis that allows users to view where the Majalis are taking place along with their contact details "addresses, and contact numbers" (e-Government Authority, 2012).

There have been huge growth of Mobile phone usage in Saudi Arabia and varieties of Mgovernment services offered including Health Mobile, which provides an interactive service via mobile phones in Saudi Arabia to keep subscribers informed about the updates in medicine, health and disease prevention by receiving daily text messages (SMS). Ministry of Higher Education provides tracking service through SMS where student get necessary information after registering names and their mobile numbers on the Ministry of Higher education web site. SMS Service by King Saud University helps Professors, Staff, and Student to communicate each other regarding academic curricula and materials for studies. iTVTC services provided by Technical and Vocational Training Corporation in order to help users to get training and information, by download the free programs on the users' smart mobile phones. IQAMA Information service provides information on the status of resident permits of users and dependents on their mobile 
phones. Traffic Offence Information service enables citizens and residents of the electronic query of traffic violations by sending SMS to the numbers designated by their mobile service provider. There are many more Mobile applications are offered or underway (Popular Mobile Applications, 2012).

Oman has started recently to utilize mobile channels to offer M-application services to its citizens and clients. Some of the major services include: SMS-Parking service which is developed by Muscat Municipality enables motorists to pay parking fees via SMS; Higher secondary school students can now retrieve their end of semester grades (via SMS) by messaging their student seat numbers to a phone number designated by the Ministry of Education. The Royal Oman Police (ROP) initiated an M-service allowing drivers to enquire and receive information about their traffic offences through sending SMS messages. Similarly, many other organizations are offering Mservices through SMS in Oman, which are needed to be explored further and to see their influence on the users.

\section{Purpose of the study}

The purpose of this exploratory study is to present a synopsis of M-application services offered by public and private organizations in Oman.

\section{Oman in Brief}

Oman is one of the Gulf Cooperation Council (GCC) member country located on the southeast part of the world. Oman had a population of 2,773,479 persons where expatriate were counted as 816,141 . Oman's currency is Rial which is about USA \$2.58 per unit OMR (Omani Rial). The country's main revenue comes from oil and natural gas. The country's economic status was substantially enhanced by rising oil prices (Ministry of Information-Oman, 2012). The GDP at current prices in Oman was reported at RO 20.53 billion in 2009, according to the International Monetary Fund (IMF). In 2015, Oman's GDP at current prices is expected to be RO 33.62 billion RO (IMF Report, 2012). Beside the economic development, Oman has made an enormous growth in deploying technology in the country. Oman has witnessed a wide spread initiative to promote e-Oman as a state-of-the-art solution in implementing the country's digital strategy. The government's growing investment and commitments in electronic services to educating users by offering training programs and awareness campaigns to promote the use of mobile technologies. It has embarked on several projects using mobile technologies to offer varieties of Mobile services to citizens, residents and businesses too.

In Oman, the total mobile users increased from 3.9 million subscribers in 2009 to 4.8 millions in year 2011 see figures Figure 1 and Figure 2, of which half of them have internet accessible mobile devices as estimated (Ministry of National Economy-Oman, 2012). A recent estimation indicated that over half of the Omani population has mobile devices, while the mobile infrastructure in Oman is currently covering 95\% of the country (Ministry of National Economy 2007).

Mobile technology with the introduction of internet enabled mobile phones, PDA's, Wi-Fi and wireless networks have allowed their users to enjoy all the benefits of telephones, information accessing, and text messaging such as SMS (Naqvi, Al-Shihi \& Ali, 2011).

Oman Telecommunications Company (Omantel) is the pioneer telecom service provider in Oman, offering fixed-line phone, mobile phone and Internet-related connectivity and hosting services. Nawras is a secondary telecom service provider in Oman, offering fixed-line phone, mobile phone and WiMax and 3G-based fixed line Internet-related services. There are several other companies such as Friendi Mobile, Samatel and Renna are in the business, providing mobile phones and value added services to their clients. 


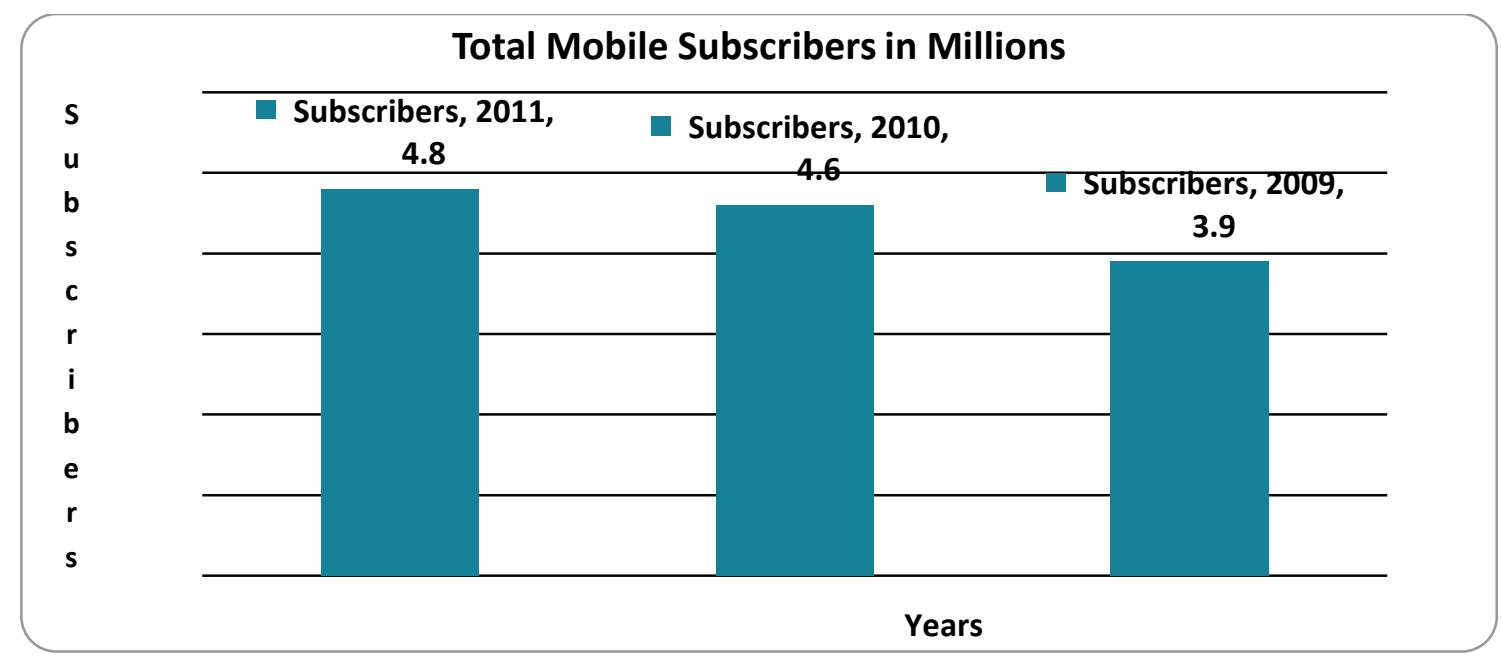

Figure 1: Mobile Subscribers

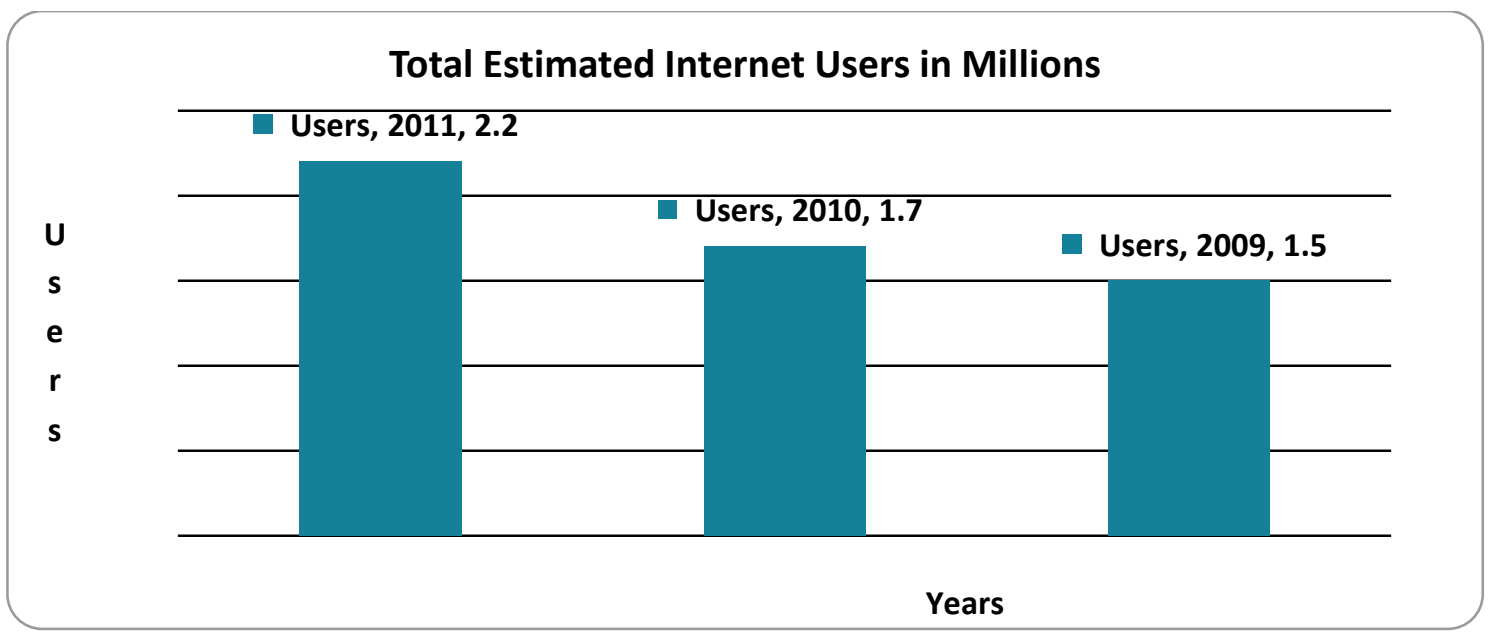

Figure 2: Internet Users

\section{Research Methods and Discussions}

To update, on the issue of M-application services initiatives in Oman, interviews were conducted with key staff in several government organizations. These organizations were chosen according to their respective experiences in offering $\mathrm{M}$-application services and only the active adopters were chosen and their key staff members were interviewed (Naqvi, Al-Shihi, 2009). The information collected is being summarized in the following four major aspects conducive for adapting to these in Oman including economic conditions, Technology resources, Government commitment and creating awareness.

\section{Economic Conditions}

Economic condition is also widely recognized as a major driver for the adoption of M-services in the country. The GDP and income per capital are common indicators for the economic condition of a country. Since M-application services rely on technology infrastructures, which are relatively 
expensive for many developing countries. The countries with unfavourable economic condition are not likely to be involved in offering $\mathrm{M}$-application services to their citizens.

Oman's economy is mainly based on oil and gas export, continues excellent performance in recent years, accounting for approximately $47 \%$ of GDP and constituting around $81 \%$ of net fiscal revenue for 2010 . The 2012 budget shows an increase of $20.8 \%$ on yearly basis in total estimated revenue at RO 8.8bn (the largest ever in terms of estimations) compared with original 2011 budget at RO 7.28bn (Oman Budget, 2012).

\section{Technological Resources}

As we know that Omantel is the leading telecom operator in Oman, providing both fixed and mobile communication services in the country. The strategy of the company remains centred on expanding the promising segments of the market by developing attractive M-application services with a particular focus on broadband solutions in order to fulfil increasing demand created by the rise of smart devices and social networks. The company has the most extensive fixed and mobile network coverage in the country, which, coupled with a customer-centric strategy, is being leveraged to create and sustain the competitive edge. Besides, with a commitment towards maintaining its leadership position, the company is continuously expanding its footprint in the developing areas. Furthermore, Omantel is continuously expanding its international connectivity to enhance its position as an international hub. In order to achieve this vision, the company's strategy remains focused on continue delivering enhanced customer services to use M-services conveniently.

\section{Government Commitment}

Government commitment and initiatives are important in introducing M-services in the country. The government eOman initiative has the vision of transforming Oman into an advanced, worldclass e-Government by integrating all Ministries and Government entities to provide faster and more effective public services online. By facilitating better interaction between citizens, businesses and Government, eOman will take Oman forward to a new age of progress and prosperity. In line with eOman initiative, several public and private organizations started utilizing the available mobile technology resources and started offering $\mathrm{M}$-application services to provide better and efficient services to their clients.

\section{Creating Awareness}

Beside the technological resources and government commitment, it is extremely necessary to create awareness among the potential users of the available M-services in the country. As we know the users may not be excited if there is a lack of awareness and unfamiliarity with the procedure for using these services. For a greater success, the service providers should invest in marketing, educating and creating more awareness on the availability of the service to consumers and what it offers and how it can be beneficial to them. This could be done by distributing brochures, which describe to the users the benefits of these services such as convenience, time saving and easy payment with other advantages. Though the organizations are creating awareness among the users, but still there is a room for improvement to offer better client services, the service provider needs to explore the opportunities to create greater awareness among the potential users of these services.

\section{Characteristics of M-Application Services}

According to Turban and Volonino, (2010), the mobile M-services have two major characteristics that differentiate it from other forms of services, which are mobility and broad reach. The users can use these services even they are on the go and at any time. In addition, we get other attributes 
such as ubiquity, convenience, instant connectivity, personalization, localization of products and services. Mobile devices create an opportunity to deliver new services to existing customers and to attract new ones. Oman has capitalized these opportunities and started offering varieties of Mapplication services of both Push and Pull type of services. The following section summarizes the major M-application services offered by the public and private organizations of Oman (Mobile services, 2012).

\section{M-Application Services-Push Type}

- Daily news in Arabic - Al Shabiba.

Al Shabiba - Mobile App brings daily news in the users' mobile devices. They are published by the Muscat Press and Publishing House who also run print media - daily Arabic newspaper 'Al Shabiba'. You can get the latest local news, as well as top headlines, prayer timings, weather, viewpoint the popular column written by Times of Oman Editor-in-Chief, city guide, phone directory, feature article, and more. This service is free of charge and can be used through smart phones or similar mobile devices. This is a very useful news sourcing service for citizens and residents of Muscat, Sultanate of Oman.

- Daily news in English - Oman Observer.

Oman Observer - Mobile App brings daily news in English to your mobile device. They are published by the Oman Establishment for Press, Publication and Advertising who also runs other print media- daily newspaper "Oman Observer" in English. You can get the latest local, sports news and news-videos on your mobile device. This service is also free of charge and can be used through smart Phones or similar devices. This is a very valuable news sourcing service for residents of Muscat, Sultanate of Oman.

\section{- Daily news in English - Times of Oman}

Times of Oman - Mobile App provides daily news in English to your mobile device. The news is published by Muscat Press and Publishing House, which also runs other print media the daily newspaper "Times of Oman" in English. However, this service, you can get the latest local news, headlines, business and technology news in to your mobile device. This service is also free of charge and can be used through smart Phones or similar devices.

\section{- Overview of Muscat Municipality iMuscat mobile service}

iMuscat is a Mobile App for Vehicle parking-related service application that can be downloaded and used free of charge if you are using a Smartphone. This service is part of Muscat Municipality's strategies and initiatives to provide easy access to Muscat Municipality services. The main objectives of the mobile application are providing citizens and residents with convenient ways to utilize Muscat Municipality services, enhancing the communication with citizens and residents, and engage them into a two-way communication and enabling Muscat Municipality to gain more information and statistics that will lead to a better planning.

- Overview of Ministry of Awqaf and Religious Affairs - Prayer Times Mobile Application service in Arabic

It is a smart phones application used to know the prayer times and provided by the Ministry of Awqaf and Religious Affairs. It includes many services such as finding Qiblah direction, knowing prayer exact times according to the area where the user is at the time of request. This mobile application includes alarms facility for any prayer timings as well as you can also find out the time left for Athan (call for the prayer) of the next prayer. This mobile application also provides a service of finding the nearest Masjid based on user location and guide user with navigation map to reach there in shortest time. Furthermore, the application has a cal- 
endar of the Islamic events during the Hijri year, as well as to the newsletters issued by the Ministry. This service is free of charge and could be used through smart phones or similar mobile devices.

\section{- Muscat Securities Market}

It has developed a paid service that enables investors to receive regular updates on market and stock alerts via SMS (Oman Mobile, 2007). The service also enables users to get a SMS every 30 minutes on market movers - top winners, losers and most active companies (Oman Mobile, 2007).

\section{- The Civil Aviation and Meteorology}

In cooperation with Oman Mobile, the Civil Aviation and Meteorology has introduced a weather forecast service for most towns in Oman that allows users to receive weather reports on their mobiles (Oman Mobile, 2007).

\section{- Banks and M-services}

Most banks in Oman are now offering M-application services where the clients can receive updates on their bank accounts activities for amount coming in or going out of their accounts.

\section{- Commercial ads and clients}

Most shopping malls and outlets are now sending their ads and promotional incentives to the local clients via the SMSs. Other organizations have also started to send bulk messages to citizens informing them about their activities and events. For example, the Public Authority for Social Insurance has currently begun a public campaign to broadcast its services and their apparent benefits to clients. One of the means used was to send advertising SMS to all residents in Oman. Another example include Oman Tender Board and Ministry of Manpower where they now send notification messages via SMSs to clients, about their transactions and/or other issues such as new tenders and job vacancies etc.

\section{M-Application Services- Pull Type}

\section{- $\quad$ The Royal Oman Police (ROP)}

Initiated an M-application service allowing drivers to inquire and receive information about their traffic offences. Motorists are required to send a message of their IDs and vehicle details to ' 90085 ' and will receive information on the number of traffic offences and amount payable. The ROP is also offering an SMS service to enquiry on vehicle registration status.

Tariff: Subscription is free and all SMS to 90085 will cost 100 Baiza each. 
Table 1: SMS services offered by Royal Oman Police

\begin{tabular}{|l|l|}
\hline \multicolumn{1}{|c|}{ SMS Service Description } & \multicolumn{1}{|c|}{ SMS Service Commands } \\
\hline $\begin{array}{l}\text { For Enquiry of All Traffic Offenses regis- } \\
\text { tered against an ID number }\end{array}$ & Send: TP $<$ ID number $>$ to 90085 \\
\hline $\begin{array}{l}\text { For Enquiry of Traffic Offenses registered } \\
\text { against a particular Vehicle }\end{array}$ & $\begin{array}{l}\text { Send: TP }<\text { ID number }><\text { Vehicle Code }> \\
<\text { Vehicle Number }>\text { to 90085 }\end{array}$ \\
\hline $\begin{array}{l}\text { For Enquiry of All Traffic Offenses regis- } \\
\text { tered against a company Commercial Regis- } \\
\text { tration Number }\end{array}$ & $\begin{array}{l}\text { Send: TC }<\text { Commercial Registration Num- } \\
\text { ber }>\text { to } 90085\end{array}$ \\
\hline $\begin{array}{l}\text { For Enquiry of Traffic Offenses registered } \\
\text { against a particular vehicle against a com- } \\
\text { pany Commercial Registration Number }\end{array}$ & $\begin{array}{l}\text { Send: TC }<\text { Commercial Registration Num- } \\
\text { ber }><\text { Vehicle Code }><\text { Vehicle Number }> \\
\text { to 90085 }\end{array}$ \\
\hline $\begin{array}{l}\text { For Enquiry of Registration Expiry Enquiry } \\
\text { of Personal Vehicle }\end{array}$ & $\begin{array}{l}\text { Send: RP }<\text { ID number }><\text { Vehicle Code }> \\
<\text { Vehicle Number }>\text { to 90085 }\end{array}$ \\
\hline $\begin{array}{l}\text { For Enquiry of Registration Expiry Enquiry } \\
\text { of Commercial Vehicles against a particular } \\
\text { vehicle }\end{array}$ & $\begin{array}{l}\text { Send: RC }<\text { Commercial Registration Num- } \\
\text { ber }><\text { Vehicle Code }><\text { Vehicle Number }> \\
\text { to 90085 }\end{array}$ \\
\hline $\begin{array}{l}\text { For enquire about the status of Visa Applica- } \\
\text { tion submitted online through the ROP web- } \\
\text { site }\end{array}$ & $\begin{array}{l}\text { Send: VS }<\text { WEB APPLICATION NUM- } \\
\text { BER }><\text { REFRENCE KEY }>\text { to 90085 }\end{array}$ \\
\hline
\end{tabular}

- Ministry of Education (MoE)The SMS service of Oman Educational Portal of the Ministry of Education is launched recently providing an easy access to information as needed by the users. The users can take benefit of this service to extract information about registered students or parent or access to exam results. The service is available for the employees of the Ministry of Education, school faculty, parents and students who are in the government schools of Oman. Some of these services are implemented through SMS such as student attendance, notices to parents, grade report and details of syllabus etc. Tariff: Subscription is OMR 1.500, but all messages sent to 90390 will cost 100 Baiza each.

Table 2: SMS services offered by Ministry of Education

\begin{tabular}{|l|l|}
\hline SMS Service Description & SMS Service Commands \\
\hline To subscribe to the service & Send SUB $<$ space $><$ Student No $>$ to 90390 \\
\hline $\begin{array}{l}\text { Level of attendance (Pending/ Present/ Ab- } \\
\text { sent) }\end{array}$ & Send A $<$ space $><$ Student No. $>$ to 90390 \\
\hline To cancel subscription & Send DEL $<$ space $><$ Student No $>$ to 90390 \\
\hline $\begin{array}{l}\text { Requesting user name \& password for edu- } \\
\text { cational portal }\end{array}$ & Send U $<$ space $><$ Parent Civil ID $>$ to 90390 \\
\hline Requesting students grade results & Send G $<$ space $><$ student ID $>$ to 90390 \\
\hline Requesting students ID list & Send L $<$ space $><$ Parent Civil ID $>$ to 90390 \\
\hline Requesting students class & Send C $<$ space $><$ Student No. $>$ to 90390 \\
\hline Requesting students elective modules & Send E $<$ space $><$ Student No. $>$ to 90390 \\
\hline Requesting students activities & Send N $<$ space $><$ Student No. $>$ to 90390 \\
\hline For help & Send $<$ HELP $>$ to 90390 \\
\hline
\end{tabular}

\section{- Muscat Municipality}


The Muscat Municipality recognizes the significance of mobile communication channels with the citizens. It has recently introduced many SMS services including Tenancy Agreement, Environment Healthiness Check, Technical Check, Building Permit follow-up, Small Permit, Violations and Passes for Paid Car-Parking.

Tariff: Subscription is free but all messages sent to 90888 will cost 20 Baiza each.

Table 3: SMS services offered by Muscat Municipality

\begin{tabular}{|l|l|}
\hline SMS Service Description & SMS Service Commands \\
\hline For Enquiring & Send SR $<$ SR number $>$ to 90888 \\
\hline $\begin{array}{l}\text { For Violations and Passes for Paid Car Park- } \\
\text { ing }\end{array}$ & $\begin{array}{l}\text { Send VE }<\text { followed by vehicle registration } \\
\text { number }><\text { code }>\text { to } 90888\end{array}$ \\
\hline To ask for help & Send [Help] to [90888] \\
\hline
\end{tabular}

- Muscat Municipality and Oman mobile SMS Parking Service

This new mobile service introduced recently for motorists to pay the parking fee in MBD (Muscat Business District) and its surrounding areas. The service is simple to use where a user should have a mobile phone with either a pre or post-paid option. The parking fee deducted instantly or sent through the user's monthly mobile phone bills. The user can park the car and send an SMS to "90091" with the details of the car plate number and the minutes for which the parking is needed. The users will get a confirmation message for a successful transaction. The user will then gets a reminder message five minutes before the allocated time expires to either move the vehicle or renew his/her parking time (Oman Mobile 2010). This flow of information from the user goes to the Oman mobile and passes to the Muscat Municipality data bank. The inspector receives the information on his PDA and uses it while inspecting the parking sites for violations.

Table 4: SMS Parking service Offered by Muscat Municipality

\begin{tabular}{|l|l|}
\hline SMS Service Description & SMS Service Commands \\
\hline For Parking & $\begin{array}{l}\text { Send }<\text { car Registration number }><\text { car } \\
\text { Code }><\text { Minutes required }>\text { to } 90091\end{array}$ \\
\hline To ask for help & Send [Help] to [90091] \\
\hline
\end{tabular}

Table 5: SMS Parking service Tariffs by minutes

\begin{tabular}{|l|c|}
\hline \multicolumn{1}{|c|}{ Service Description } & Cost \\
\hline 30 minutes parking time & 60 Baiza \\
\hline 60 minutes parking time & 110 Baiza \\
\hline 90 minutes parking time & 160 Baiza \\
\hline 120 minutes parking time & 210 Baiza \\
\hline 150 minutes parking time & 260 Baiza \\
\hline 180 minutes parking time & 310 Baiza \\
\hline 210 minutes parking time & 360 Baiza \\
\hline 240 minutes parking time & 410 Baiza \\
\hline 270 minutes parking time & 460 Baiza \\
\hline 300 minutes parking time & 510 Baiza \\
\hline Help SMS & 10 Baiza \\
\hline Time SMS & 10 Baiza \\
\hline Status SMS & 10 Baiza \\
\hline
\end{tabular}

\section{- Ministry of Civil Services}


With the vision of providing superior quality services to job seekers in government sector and observing the suffering of applicants endless hours spend on inquiry about new available positions via phone or in news paper and inquiry about test results and interviews, ministry of civil services is offering subscription based SMS services. Directorate General of Employment and Training Employment plays a central module of the functions of government agencies under the Civil Service Law.

Tariff: Subscription of six months is one Rial, but all messages sent to 90226 will cost 50 Baiza each.

\section{Table 6: SMS offered by Ministry of Civil Services}

\begin{tabular}{|l|l|}
\hline SMS Service Description & SMS Service Commands \\
\hline To register for the service & Send $<$ T $>$ to 90226 \\
\hline If you send 'T' again to 90226 & Send $<$ T $>$ to 90226 \\
\hline $\begin{array}{l}\text { To cancel the MoCS SMS Registration Ser- } \\
\text { vice }\end{array}$ & Send $<$ H $>$ to 90226 \\
\hline To Get 'help' of The Service & Send 'help' to 90226 \\
\hline To Apply for a job & $\begin{array}{l}\text { Send AP }<\text { Manpower ID }>\text { \# }<\text { Vacancy } \\
\text { Number }>\text { to } 90226\end{array}$ \\
\hline Test Date for job & $\begin{array}{l}\text { Send TD }<\text { manpower ID }>\text { \# }<\text { job number }> \\
\text { to } 90226\end{array}$ \\
\hline
\end{tabular}

- Ministry of Manpower

The M-application service offered by the Ministry of Manpower is highly valuable for jobseekers by giving all information pertaining to job opportunities available in the private sector. It also helps companies to implement their Omanization process smoothly by acknowledging the current status of Omanis in their organisations. The user can request for information, notifications and also to track the status of services provided by visiting the ministry's website (www.manpower.gov.om) and follow the directions to benefit from this service (Ministry of Manpower-Oman, 2012).

Tariff: Subscription fee is OMR 60 per year.

- Job vacancy alert System (Tashgheel)

This service provides information about job opportunities available in the private sector of Oman. The user can submit his/her CV online and receive an SMS whenever any job opportunity matches the qualifications and interests. The SMSs are sent, about new job vacancies, to job seekers with the "Vacant job numbers" as announced by the Ministry of Manpower. The Job seekers then have two options: 1 . Accept or 2. Reject the job offer by sending SMS to 90017 along with the vacancy identification number sent earlier.

\section{Table 7: SMS Services offered by Ministry of Manpower}

\begin{tabular}{|l|l|}
\hline SMS Service Description & SMS Service Commands \\
\hline To accept job vacancy & Send A $<$ Vacant job number $>$ to 90017 \\
\hline To reject job vacancy & Send R $<$ Vacant job number $>$ to 90017 \\
\hline $\begin{array}{l}\text { Tracking System: For enquiring the service } \\
\text { status }\end{array}$ & Send $<$ reference number $>$ to 90017 \\
\hline Tracking System: For Labour Card Details & Send LC $<$ resident card no $>$ to 90017 \\
\hline $\begin{array}{l}\text { Tracking System: For Omani registration } \\
\text { details }\end{array}$ & $\begin{array}{l}\text { Send OR }<\text { manpower ID number }>\text { to } \\
90017\end{array}$ \\
\hline
\end{tabular}


SMS Service Description

Tracking System: For Labour Suspension

Status

Tracking System: For Suspension Detail status
SMS Service Commands

Send LS $<$ Commercial registration $(\mathrm{CR})$ number $>$ to 90017

Send $\mathrm{SD}<\mathrm{CR}$ number $>$ to 90017

\section{- Higher Education Admission Center}

The Higher Education Admission Center is offering many SMS services for students. The students have to use the same GSM phones, as registered in the center's database. The students should send an SMS to 90190 with acceptable format for the information required as shown in Table 8 . The student will receive a reply after a few minutes for each message sent regardless in correct or incorrect format. If student do not receive any reply then it means that the system did not received message and it needs to be resend.

Tariff: Messages sent to 90190 will cost 75 to 100 Baiza / message

Table 8: SMS Services Offered by Higher Education Center

\begin{tabular}{|l|l|}
\hline SMS Service Description & SMS Service Commands \\
\hline For Help & Send $<$ H $>$ to 90190 \\
\hline For Add Low income & Send AL $<$ HEAC No $>$ to 90190 \\
\hline For Change Programs & $\begin{array}{l}\text { Send CP }<\text { HEAC No }><\text { Old prg }><\text { New } \\
\text { prg }>\text { to } 90190\end{array}$ \\
\hline For Information & Send $<$ I $>$ to 90190 \\
\hline For View Low income & Send VL $<$ HEAC No $>$ to 90190 \\
\hline For Registration number & Send R $<$ Civil No $>$ to 90190 \\
\hline For Getting HEAC Number & $\begin{array}{l}\text { Send GH }<\text { Civil No Set No GSM No }>\text { to } \\
\text { 90190 }\end{array}$ \\
\hline For Delete Low income & Send DL $<$ HEAC No $>$ top 90190 \\
\hline For Programs & Send P $<$ HEAC No $>$ to 90190 \\
\hline For Personal Information & Send PI $<$ HEAC No $>$ to 90190 \\
\hline For Change GSM number & $\begin{array}{l}\text { Send CG }<\text { Civil No }>\text { HEAC No }><\text { GSM } \\
\text { No }>\text { to } 90190\end{array}$ \\
\hline For View Social Sec & Send VS $<$ HEAC No $>$ to 90190 \\
\hline For Add Social security & $\begin{array}{l}\text { Send AS }<\text { HEAC No }><\text { Social No }>\text { to } \\
90190\end{array}$ \\
\hline For Register Programs & Send RP $<$ HEAC No $><$ Prg Co $>$ to 90190 \\
\hline For Grades & Send G $<$ HEAC No $>$ to 90190 \\
\hline For Social security status & Send S $<$ HEAC No $>$ to 90190 \\
\hline For Insert Programs & $\begin{array}{l}\text { Send IP }<\text { HEAC No }<<\text { Prg Co }><\text { Prg or- } \\
\text { der }>\text { to } 90190\end{array}$ \\
\hline For Offered program & Send O $<$ HEAC No $>$ to 90190 \\
\hline For Delete Social Sec & Send DS $<$ HEAC No $>$ to 90190 \\
\hline For Delete Programs & Send DP $<$ HEAC No $><$ Prg Co $>$ to 90190 \\
\hline For Accept offer & Send A $<$ HEAC No $>$ to 90190 \\
\hline For Criteria & Send C $<$ Prg Co $>$ to 90190 \\
\hline For Finding eligible program & Send EP $<$ HEAC No $>$ to 90190 \\
\hline
\end{tabular}




\section{Conclusion and Future Work}

The advancement of mobile technology is paving the way for people to incorporate these devices into their daily lives effective and efficiently. This progression of mobile technology has created opportunities for government or private organizations of developed and developing nations including Oman and its neighbouring countries to transition their services to mobile platform.

Oman is an emerging country and adapting to the new technologies. These technologies play a pivotal role in Oman and helping significantly in moving forward its national development process. Oman has just started to utilize mobile channels to offer M-application services to its citizens and clients. Some of the examples include; Muscat Municipality's SMS-Parking Service system that enables motorists to pay parking fee via SMS. Higher secondary school students can now retrieve their end of semester grades (via SMS), by messaging their student seat numbers to a phone number designated by the ministry of education. Muscat Securities Market sends updates on market and stocks alerts to investors via SMS. Similarly, many other organizations are also offering varieties of such services through SMS, messaging clients to inform them about their different activities. Due to continuous economic and technological advancement and the current initiatives taken by the government and private organizations, it is expected that in coming years, more $\mathrm{M}$-application services will be offered in Oman using the advanced mobile resources. This exploratory research has presented a synopsis of $\mathrm{M}$-application services offered in Oman, which paves the way for a comprehensive future studies including their successes and failures. Many experts have doubts on the bright future of mobile application services. Some say as websites across the globe develop mobile compatible interfaces and as mobiles get smarter many tasks, which require mobile applications, may be shifted to web again.

\section{References}

e-government on line services. (2013). Retrieved March 10, 2013 from http://www.ictqatar.qa/en/department/national-programs/ict-infrastructure/

e-Government Authority. (2012). Retrieved March 10, 2013 from http://www.bahrain.bh/wps/portal/!ut/p/c5/04 SB8K8xLLM9MSSzPy8xBz9CP0os3g3E0cj0wAXIw MDvwBXAyNLbw8jkxBXI3dzA 1wkA6zeGd3Rw8Tcx8DAwsXNwsDIydTM89AAxcDA09TiLwB DuBooO nkZ-bqhcWKRfkJ2d5uioqAgAS8Mevg!!/dl3/d3/L01HSkovd0RNQU5rQUVnQSEhL11CZncvZW4!/

IMF Report. (2012). Oman GDP at current prices. Retrieved August 24, 2012 from, http://www.tradingeconomics.com/oman/gdp-at-current-prices-imf-data.html

Ministry of Manpower-Oman. (2012). Jobs information. Retrieved August 22, 2012 from http://www.manpower.gov.om/ar/index.asp

Ministry of National Economy - Oman. (2007). Statistical year book, Vol. 35.

Ministry of National Economy - Oman. (2012). Retrieved August 6, 2012 from, http://www.oman.om/wps/portal

Mobile services. (2012). Mobile services, Retrieved August 14, 2012, from http://www.oman.om/wps/portal//ut/p/c0/04 SB8K8xLLM9MSSzPy8xBz9CP0os hgL2nYE8TIwN PyNTA89Qt1CzILcgQ3dnc 2CbEdFAKUhac!/?WCM GLOBAL CONTEXT=/wps/wcm/connect/en/site/home/Mobservices

Naqvi, S., \& Al-Shihi, H. (2009). M-Government initiatives in Oman. Issues in Informing Science and Information Technology, 6, 817-824. Retrieved from http://iisit.org/Vol6/IISITv6p817-824Naqvi678.pdf

Naqvi, S., Al-Shihi, H., \& Ali, S. (2011). Mobile services in Oman: A feedback on SMS-parking service. Proceedings of Information Science \& IT Education (InSITE), USA, 383-391. Retrieved from http://proceedings.informingscience.org/InSITE2011/InSITE11p383-391Naqvi330.pdf 
OMAN Budget. (2012). Retrieved August 22, 2012 from http://www.menafn.com/updates/research_center/Oman/Economic/0ab160112e.pdf

Oman Mobile. (2007). Products and services. Retrieved May 5, 2008 from http://www.omantel.om/default.aspx

Oman Mobile. (2010). Products and services., Retrieved August 8, 2010 from http://www.omantel.net.om

Popular Mobile Applications. (2012). Retrieved March 10, 2013 from http://blog.ethosinteract.com/2012/09/27/most-popular-mobile-applications-in-saudi-arabia

Turban, E., \& Volonino, L. (2010). Information technology for management-transforming organizations in the digital economy. John Wiley \& Sons.

UAE turn to mobile and social media applications. (2013). Retrieved March 10, 2013 from http://www.ameinfo.com/277705.html

\section{Biographies}

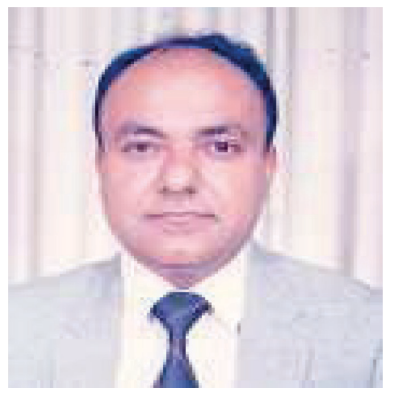

Dr. Syed J. Naqvi is an Assistant Professor in the Department of Information Systems, College of Economics and Political Science at Sultan Qaboos University. Prior to this he worked at many other prestigious universities including University of Maryland, University of Kentucky, East Texas State University and University of Petroleum and Minerals, Dhahran, Saudi Arabia and published widely on Computers and Information Systems education. His teaching interests include programming languages, Web applications development, e-commerce and MIS with research interest in Mobile Technology and computer education.

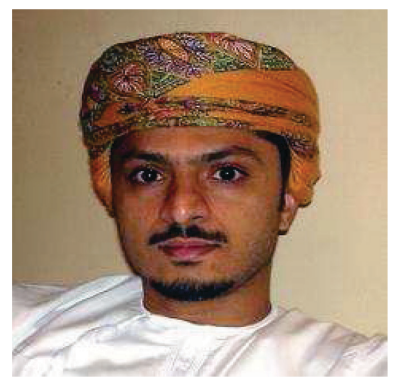

Dr. Hafedh Al-Shihi is an Assistant Professor at the College of Economics and political Science in Sultan Qaboos University. He did his $\mathrm{PhD}$ in e-Government at Victoria University in Melbourne, Australia in 2006, and his MS in Computer and Information Systems at University of Detroit Mercy in Michigan, USA. He is a member of the Association of Information Systems (AIS) and the Special Interest Group on Electronic Government (SIGeGov). He is also a Research Associate in the Center for International Corporate Governance Research at Victoria University, Australia. He has several publications on e-government adoption and dissemination. He has supervised several undergraduate, masters and $\mathrm{PhD}$ researches. Currently, he is teaching introductory and major Information Systems (IS) courses to undergraduate students and supervising the Information Systems Group at the Sultan Qaboos University (www.isg-zone.com). 